\title{
Antimicrobial activities of herbal plants from Uzbekistan against human pathogenic microbes
}

\author{
Dilfuza Egamberdieva ${ }^{1,2}$ (D) Dilfuza Jabborova ${ }^{3} \cdot$ Svetlana Babich $^{4} \cdot$ Sokhiba Xalmirzaeva $^{4}$. \\ Kamaliddin Salakhiddinov ${ }^{4} \cdot$ Madamin Madazimov $^{4}$
}

Received: 1 August 2020 / Revised: 29 October 2020 / Accepted: 3 November 2020 / Published online: 24 November 2020

(C) The Author(s) 2020

\begin{abstract}
In traditional medicine of Uzbekistan, around $20 \%$ of herbal plants are used to treat various ailments, including diseases caused by pathogenic bacteria and fungi. Though conventional medicinal plants are common in Uzbekistan, many plant species potentially useful for new pharmaceuticals are less studied. They contain various biological compounds with antibacterial and antifungal activities, that could be developed into drugs. The search for novel antimicrobial compounds, especially against multidrug-resistant pathogens from aromatic and herbal plants is an essential scientific research line. However, the antimicrobial properties of several medicinally important plants from various countries are still unknown. This review aims to provide an up-to-date report on the antimicrobial activity of medicinal plants endemic to Uzbekistan widely used in traditional medicine.
\end{abstract}

Keywords Medicinal plants · Metabolites · Antibacterial activity · Antifungal activity Uzbekistan

\section{Introduction}

It is estimated that about 50,000 plant species were screened for medicinal properties and used by $80 \%$ of the world's population to treat numerous human diseases (SaslisLagoudakis et al. 2014; Chen et al. 2016). Uzbekistan is known for its endemism, in which $9 \%$ of 4500 species of vascular plants are considered endemic (Mamedov et al. 2004). Though traditional medicinal plants are common in Uzbekistan, many plant species potentially useful for new pharmaceuticals are less studied. The remedies derived from natural resources are widely used to treat numerous illnesses, including respiratory and urinary problems, gastrointestinal, and skin disorders as age-old tradition (McChesney et al.

Dilfuza Egamberdieva

egamberdieva@yahoo.com

1 Faculty of Biology, National University of Uzbekistan, Tashkent, Uzbekistan

2 Leibniz Centre for Agricultural Landscape Research (ZALF), Müncheberg, Germany

3 Institute of Genetics and Plant Experimental Biology, Academy of Sciences of Uzbekistan, Tashkent, Uzbekistan

4 Andijan State Medical Institute, Otabekov Str. 1., Andijan, Uzbekistan
2007). Since the cost of synthetic, medicinal drugs is high, the developing countries are still using herbal plants or their derivates to treat common diseases (Abu-Irmaileh and Afifi 2000). It is known that multidrug-resistant bacterial pathogens signify a growing public health threat. Therefore, there is a continuous need for effective natural therapeutic agents (Compean and Ynalvez 2014). The investigation of aromatic and herbal plants for their biologically active constituents might lead to discovery of new drugs with antimicrobial activities (Cushnie and Lamb 2005; Shrivastava et al. 2015). The medicinal plants contain various metabolites that demonstrate antimicrobial activity in vitro and vivo (Duarte et al. 2005). Many secondary metabolites derived from herbal plants from multiple countries were screened against microbes that cause various infections (Pirbalouti et al. 2010; Verma et al. 2012; Gnat et al. 2017; Egamberdieva and da Silva 2015). For example, Indian and the Middle East's medicinal plants are used for treating infectious diseases in traditional medicine (Duraipandiyan et al. 2011). Medicinal plants containing various phytochemical compounds, such as antimicrobials, essential oils, alkaloids, are also used to treat wound infections (Bahramsoltani et al. 2014). Wound healing is a critical biological process required to minimize potential infections (Gupta and Jain 2010). Finding novel biological agents for the treatment of 
wound infections generated increased interest over time. There are many reports on medicinal plants' antimicrobial properties against human pathogenic bacteria involved in skin and wound infections.

Moreover, medicinal plants associated with microbes, which play an essential role in plant health, synthesize various biologically active compounds due to the symbiosis (Egamberdieva et al. 2020; Rusatmova et al. 2020; Musa et al. 2020). It has been proven that medicinal plants with antimicrobial activity support more antagonistic endophytic bacteria against human pathogenic microbes. Many medicinal plants contain useful essential oils with antimicrobial properties (Nikolic et al. 2014). In an earlier study, the plant extracts of Zingiber officinales and Thymus kotschyana suppressed the growth of human pathogenic bacteria Staphylococcus aureus and Escherichia coli Qader et al. (2013). Similar reports demonstrated an inhibitory activity of plant extracts of Z. officinales and Allium sativum against Staphylococcus aureus (Betoni et al. 2006; Ushimaru et al. 2007; Sapkota et al. 2012). The plant extracts of Boerhaavia diffusa, Tribulus terrestris, and Soymida febrifuga inhibited E. coli, Enterococcus faecalis, Klebsiella oxytoca and $S$. aureus (Mishra et al. 2017). In the current era, several new infectious diseases appear worldwide. Thus, there is a great need to discover new biologically active compounds from herbal plants and develop novel drugs. Few reports are available about Uzbekistan's herbal plants and their constituents with antimicrobial activities (Kogure et al. 2004), and these endemic plants may contain pharmaceutically essential compounds. According to Gaipova and Kariyeva (2018), during the years 2015-2018, 46 natural products based on medicinal herbs were registered in Uzbekistan. Among them, Origani vulgaris, Ziziphora pedicellata, Aerva lanata, Calendula officinalis, and Chamomilla officinalis K.Koch based products are widely used.

\section{Medicinal plants of Uzbekistan and their antimicrobial activity}

In traditional medicine of Uzbekistan, around $20 \%$ of herbal plants are used for treating various ailments (Mamedov et al. 2004: Shurigin et al. 2018; Egamberdieva and Jabborova 2018). The plant species described in Avicenna's book, such as Malva silvestris L., Cannabis sativa L., Ferula assafoetida L., Sesamum indicum L., Pyrus malus L., Punica granatum L., and Trachyspermum ammi L. are used till today to treat various illnesses (Buranova 2015). Many of these species are used to heal wounds (Khodzhimatov 1989; Egamberdieva et al. 2017b).

The extract of Thymus seravschanicus is known as an antimicrobial agent for handling throat ailments (Kholmatov and Makhsumov 1993). Azizov et al. (2012) reported the commonly used plant species Arctium lappa in Uzbekistan, which was used to treat skin infections. Origanum tyttanthum, widely grown in many Uzbekistan parts, exhibited antimicrobial, hypocholesterolemic, and hypolipidemic activity (Nuraliyev and Zubaidova 1994).

The plant extract of Hypericum perforatum collected from the Chatkal Biosphere Reserve of Uzbekistan demonstrated antagonistic activity against Pseudomonas aeruginosa, E. coli, E. faecalis, K. oxytoca, Klebsiella pneumoniae, and S. aureus (Egamberdieva et al. 2013). Yili et al. (2009) reported the antimicrobial activity of Anethum graveolens against human pathogens such as Candida albicans and $S$. aureus. In other studies, Silene wallichiana, Silene viridiflora, and Silene brahuica inhibited several Gram-negative and Gram-positive human pathogenic bacteria (Mamadalieva et al. 2008). Moreover, the chloroform extracts of endemic plant Ajuga turkestanica Rgl. Brig demonstrated antimicrobial activities against $S$. aureus and Streptococcus pyogenes (Mamadalieva et al. 2012). The extract prepared from Aconitum was used in veterinary medicine for skin wounds and ulcers (Aldashev 1979). Kwon et al. (2005) found an inhibitory activity of shoot and leaves of Agrimonia eupatoria against hepatitis B virus in vitro experiments. Sonboli et al. (2006) reported the antibacterial and antifungal activity of Ziziphora species. Plant extracts of $H$. perforatum showed antagonistic properties against human pathogenic bacteria, E. faecalis, K. oxytoca, K. pneumoniae, Klebsiella aerogenes, Citrobacter freundii, S. aureus, P. aeruginosa, and E. coli (Egamberdieva et al. 2017b). List of some of the known medicinal plants from Uzbekistan with antimicrobial properties is presented in Table 1.

\section{The antimicrobial activity of biologically active compounds derived from medicinal plants}

The medicinal plants contain many important bioactive constituents such as terpenoids, essential oils, polyphenols, and flavonoids. These compounds demonstrated numerous biological activities; such as sedative, analgesic, antibacterial, and anti-inflammatory activities (Dall'Agnol et al. 2003). Antibacterial properties of biologically active compounds isolated from $H$. perforatum were reported by Dall'Agnol et al. (2003). The antibacterial and antifungal activities were observed in flavonoids and essential oils of Ziziphora species (Sonboli et al. 2006). Tada et al. (2002) isolated several biologically active compounds such as coumarins, terpenoids, and glycosides from Prangos pabularia roots that exhibited antibacterial activity. Phytoecdysteroids isolated from $S$. wallichiana demonstrated antimicrobial properties against various human pathogenic microbes (Mamadalieva et al. 2013). Park et al. (2000) separated the peptides shepherin from Capsella bursa's roots and observed the biologically active compound's antimicrobial activity against human pathogenic microbes. Mamadalieva et al. (2011) extracted 
Table 1 The medicinal plants of Uzbekistan with antimicrobial activities

\begin{tabular}{|c|c|c|c|}
\hline Plant species & Family & Part used & Chemical composition \\
\hline Achillea millefolium $\mathrm{L}$ & COMPOSITAE & Steam, leaves, flowers & $\begin{array}{l}\text { Volatile oils, lactons (achillicin, matricin), } \\
\text { alkaloids, flavonoids, betains (Sezik } \\
\text { et al. 2004) }\end{array}$ \\
\hline Aconitum talassicum & RANUNCULACEAE & Aerial parts & Alkaloids (Aldashev 1979) \\
\hline Acroptilon picris & ASTERACEAE & Aerial parts & Volatile (Norouzi-Arasi et al. 2006) \\
\hline Agrimonia asiatica Juz & Rosaceae & Leaves, stem & $\begin{array}{l}\text { Ursolic acid, tannins, flavonol glycosides, } \\
\text { B-vitamins, saponins, trace alkaloids } \\
\text { (Eisenman et al. 2013) }\end{array}$ \\
\hline Ajuga turkestanica & LAMIACEAE & Root & $\begin{array}{l}\text { 20-hydroxy-esdysone,turkesterone, cyas- } \\
\text { terone }\end{array}$ \\
\hline Anethum graveolens & Apiaceae & Whole plant & $\begin{array}{l}\text { Essential oil (Carvone, limonene, cis- } \\
\text { dihydrocarvone, diplaniol, 1,2-diethox- } \\
\text { yethane) (Yili et al. 2009) }\end{array}$ \\
\hline Artemisia absinthium $\mathrm{L}$ & COMPOSITAE & Whole plant & Volatile oils (Sezik et al. 2004) \\
\hline Artemisia dracunculus & ASTERACEAE & Whole plant & (Curini et al. 2006) \\
\hline $\begin{array}{l}\text { Arischrada korolkowii Regel et } \\
\text { Schmalh. Pobed }\end{array}$ & LAMIACEAE & & Essential oil (Baser et al. 2002) \\
\hline Asparagus persicus Baker & LILIACEAE & Leaves, root, stem & $\begin{array}{l}\text { Saponin, volatile oil, flavonoids, tannins, } \\
\text { steroidal and bitter glycosides, tyrosine, } \\
\text { ecdysteroids (Mamedov and Craker } \\
\text { 2001) }\end{array}$ \\
\hline Astragalus sieversianus Pall & FABACEAE & Aerial part & $\begin{array}{l}\text { Saponins, alkaloids, coumarins, tannins, } \\
\text { flavonoids, vitamins C, E, and P, and } \\
\text { carotene (Eisenman et al. 2013) }\end{array}$ \\
\hline Berberis integerrima & BERBERIDACEAE & Fruit & (Khodzhimatov 1989) \\
\hline Bunium persicum & APIACEAE & Whole plant & (Sardari et al. 1998) \\
\hline Betula verrucosa Ehrh & BETULACEAE & Oil, bark leaves & $\begin{array}{l}\text { Flavonoids, tannins, volatile oils, triterpen } \\
\text { (Mamedov and Craker 2001) }\end{array}$ \\
\hline Bidens tripartita $\mathrm{L}$ & COMPOSITAE & Whole plant & $\begin{array}{l}\text { Flavonoids, volatile oils (Mamedov and } \\
\text { Craker 2001) }\end{array}$ \\
\hline Calendula officinalis $\mathrm{L}$ & COMPOSITAE & Flowers, oil & $\begin{array}{l}\text { Triterpene, volatile oils, faradiol, lauric } \\
\text { acid, carotinoids, (Mamedov and Craker } \\
\text { 2001) }\end{array}$ \\
\hline Capsella bursa & BRASSICACEAE & Roots & Peptides (Park et al. 2000) \\
\hline Carum carvi & APIACEAE & Fruit & Essential oil, (Iacobellis et al. 2005) \\
\hline Ceratocephala testiculata & RANUNCULACEAE & Whole plant & (Khalmatov 1964) \\
\hline Centaurea belangeriana Stapt & COMPOSITAE & Flower & $\begin{array}{l}\text { Glicoside, athocyane, coumarine (Sezik } \\
\text { et al. 2004) }\end{array}$ \\
\hline Dianthus tetralepis Nevski & CARYOPHYLLACEAE & Aerial part & $\begin{array}{l}\text { Anthochanin, saponins, flavones, triter- } \\
\text { pene glycosides (Sezik et al. 2004) }\end{array}$ \\
\hline Equisetum arvense $\mathrm{L}$ & EQUISETACEAE & Steam & $\begin{array}{l}\text { Falvonoids, chlorogenic acid, silicis acid } \\
\text { (Mamedov and Craker 2001) }\end{array}$ \\
\hline Erodium Hoeffitianum CAM & GERANIACEAE & Aerial part & $\begin{array}{l}\text { Polyphenolic compounds, phenolic acids, } \\
\text { tannins, flavonoids (Mamedov and } \\
\text { Craker 2001) }\end{array}$ \\
\hline Ferula kuhistanica & APIACEAE & Fruit & (Tamemoto et al. 2001) \\
\hline Helichrysum arenarium $\mathrm{L}$ & COMPOSITAE & Flowers & $\begin{array}{l}\text { Flavonoids, steroids (Mamedov and } \\
\text { Craker 2001) }\end{array}$ \\
\hline Hypericum perforatum $\mathrm{L}$ & HUPERICACEAE & Leaves, flowers, oil & $\begin{array}{l}\text { Antracene, hypericin, tannins, flavonoids, } \\
\text { xanthone (Mamedov and Craker 2001) }\end{array}$ \\
\hline Impatiens parviflora & BALSAMINACEA & Whole plant & (Khalmatov 1964) \\
\hline Juniperus turkestanica & CUPRESSACEAE & Whole plant & Essential oil (Minayeva 1991) \\
\hline Leonurus turkestanicus $\mathrm{L}$ & LABIATAE & Whole plant & $\begin{array}{l}\text { Volatile oils, diterpenes, oleic acid } \\
\text { (Mamedov and Craker 2001) }\end{array}$ \\
\hline
\end{tabular}


Table 1 (continued)

\begin{tabular}{|c|c|c|c|}
\hline Plant species & Family & Part used & Chemical composition \\
\hline Limonium otolepis (Srenck) Ktze & PLUMBAGINEACEAE & Aerial part & $\begin{array}{l}\text { Flavonoids, tannin (Mamedov and Craker } \\
\text { 2001) }\end{array}$ \\
\hline Matricaria chamomilla $\mathrm{L}$ & COMPOSITAE & Flowers & $\begin{array}{l}\text { Volatile oil, flavonoids, chrysospenol } \\
\text { (Mamedov and Craker 2001) }\end{array}$ \\
\hline Melissa officinalis $\mathrm{L}$ & LABIATAE & Whole plant & $\begin{array}{l}\text { Volatile oils, eugenol, flavonoids, triter- } \\
\text { pene (Mamedov and Craker 2001) }\end{array}$ \\
\hline Origanum vulgare $\mathrm{L}$ & LABIATAE & Leaves, flowers & $\begin{array}{l}\text { Flavonoids, volatile oils, terpinene (Sezik } \\
\text { et al. 2004) }\end{array}$ \\
\hline Origanum tyttanthum Gontsch & LAMIACEAE & Aerial part & $\begin{array}{l}\text { Essential oil, phenolic compounds, gluco- } \\
\text { sides (Baser et al. 1997) }\end{array}$ \\
\hline Padus avium & ROSACEAE & Aerial part & (Kumarasamy et al. 2002) \\
\hline Peganum harmala $\mathrm{L}$ & ZYGOPHYLLACEAE & Seeds, roots & Alkaloids (Sezik et al. 2004) \\
\hline Plantago ovata $\mathrm{L}$ & PLANTAGINACEAE & Leaves & $\begin{array}{l}\text { Fatty oil, alkaloids (plantagonine) (Mame- } \\
\text { dov and Craker 2001) }\end{array}$ \\
\hline Polygonum aviculare $\mathrm{L}$ & POLYGONACEAE & Roots, aerial part & $\begin{array}{l}\text { Flavonoids, tannins, silicic acid (Mame- } \\
\text { dov and Craker 2001) }\end{array}$ \\
\hline Prangos pabularia & APIACEAE & Leaves & $\begin{array}{l}\text { Coumarins, terpenoids, and glycosides } \\
\text { (Tada 2002) }\end{array}$ \\
\hline Rosa canina & ROSACEAE & Leaves & (Khalmatov et al. 1984) \\
\hline Scrophyllaria striata Boiss & SCROPHYLLARIACEAE & Aerial part & $\begin{array}{l}\text { Glycoside, saponin (Mamedov and Craker } \\
\text { 2001) }\end{array}$ \\
\hline $\begin{array}{l}\text { Scutellaria ramosissima } \\
\text { (Lamiaceae) }\end{array}$ & $\begin{array}{l}\text { Epilepsy, allergy, various inflammations, } \\
\text { nervous disorders, hypertension, cyto- } \\
\text { toxic and antimicrobial activity }\end{array}$ & & $\begin{array}{l}\text { Flavanoids, glucosides, lipids (Yuldasheva } \\
\text { et al. 2014) }\end{array}$ \\
\hline Tanacetum vylgare $\mathrm{L}$ & COMPOSITAE & Whole herb & $\begin{array}{l}\text { Volatile oil, flavonoids (Mamedov and } \\
\text { Craker 2001) }\end{array}$ \\
\hline Thymus vulgaris $\mathrm{L}$ & LABIATAE & Aerial part, oil & $\begin{array}{l}\text { Volatile oil, thymol, carvacrol, terpinene, } \\
\text { flavonoids (Mamedov and Craker 2001) }\end{array}$ \\
\hline Trifolium pretense $\mathrm{L}$ & FABIACEAE & Flower, aerial parts & $\begin{array}{l}\text { Coumarine, carotinoides (Mamedov and } \\
\text { Craker 2001) }\end{array}$ \\
\hline Tribulus terrestris & ZYGOPHYLLACEAE & Aerial parts & (Bedir et al. 2002) \\
\hline Xanthium strumarium & ASTERACEAE & Aerial parts & (Murillo-Alvarez et al. 2001) \\
\hline Ziziphora bungeana & LAMIACEAE & Aerial parts & Essential oil (Sonboli et al. 2006) \\
\hline Zygophyllum oxianum & ZYGOPHYLLACEAE & Aerial parts & (Zaidi and Crow 2005) \\
\hline
\end{tabular}

flavonoids scutellarin and pinocembrin from Scutellaria immaculata and Scutellaria ramosissima, which showed antimicrobial activity against human pathogenic bacteria. In another study diterpene, methyl carnosate isolated from the Salvia officinalis leaves showed antimicrobial properties against Bacillus cereus (Climati et al. 2013). The coumarins, terpenoids, and glycosides from P. pabularia exhibited strong antibacterial properties (Tada et al. 2002). The phytoecdysteroids and iridoids of $A$. turkestanica demonstrated antimicrobial activities against human pathogenic microbes (Mamadalieva et al. 2013, 2018).

The human pathogens such as C. albicans, Xanthomonas maltophilia, and Proteus mirabilis were inhibited by Artemisia dracunculus essential oil (Curini et al. 2006). The essential oils of Artemisia absinthium and Artemisia vulgaris demonstrated a wide range of antimicrobial activity (Blagojevic et al. 2006). Norouzi-Arasi et al. (2006) reported inhibitory activity of the essential oil of Acroptilon repens L. against Staphylococcus saprophyticus and Staphylococcus epidermidis. The essential oil of Cuminum cyminum L. and Carum carvi L. showed antibacterial activity against various Gram-positive and Gram-negative bacteria (Iacobellis et al. 2005). $C$. albicans and $S$. aureus growth in plates were inhibited by essential oils of $A$. graveolens (Yili et al. 2009). The essential oil derived from Pyrus salicifolia exhibited antimicrobial activity against $S$. aureus, Bacillus subtilis, and E. coli (Mamadalieva et al. 2018). In another study, the essential oil of Origanum vulgare sp. vulgare showed antimicrobial activity against ten human pathogenic bacteria (Sahin et al. 2004).

Vanitha et al. (2020) studied the medicinal plant Plumbago zeylanica L. for antimicrobial activity. In their study, the new bioactive molecule, namely heneicosane, showed 

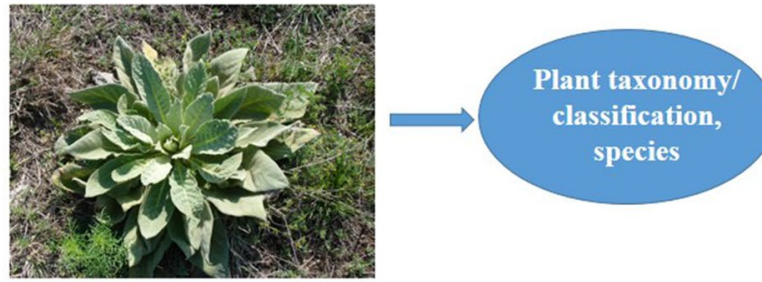

Medicinal plant

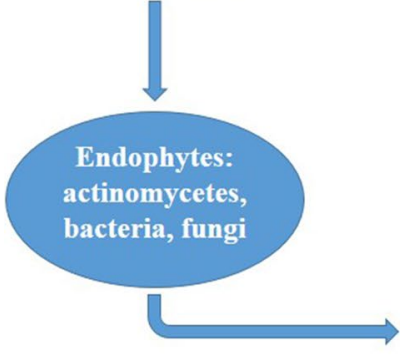

Antimicrobial activity

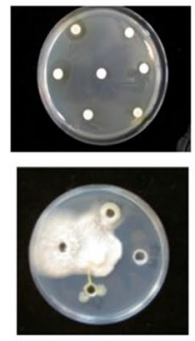

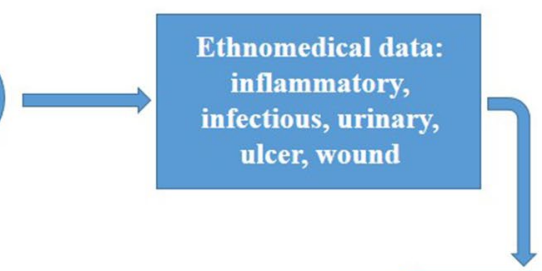

Pharmacological activities: antibacterial, antifungal, antiviral Proanthocyanidin
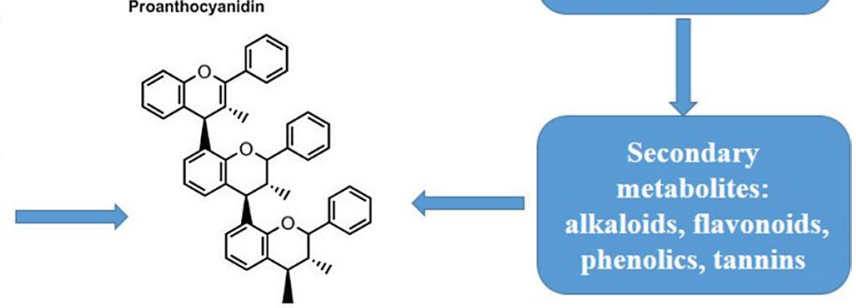

Antimicrobial compounds

Fig. 1 The potential of medicinal plants and their associated microbes in the discovery of new antimicrobial agents

potent antimicrobial activity against Streptococcus pneumoniae and Aspergillus fumigatus at $10 \mu \mathrm{g} / \mathrm{ml}$ concentrations. In other studies, biologically active compounds from medicinal plants Eurya acuminata and Croton caudatus hexatriacontan-1-ol and henicosan-1-ol showed antimicrobial activity against $C$. albicans and Mycobacterium smegmatis, respectively (Neipihoi et al. 2020). Kianfe et al. (2020) studied the antimicrobial activity of extract and fractions of Crinum glaucum A. Chev. The compound ungeremine showed significant activity against $E$. faecalis and $P$. aeruginosa, while adenosine exhibited moderate activity against $P$. mirabilis. It is known that plant tissues are host for microbes that produce various secondary metabolites with biological activity, such as antimicrobial, anticancer agents, and antioxidants alongwith the plant growth regulators (Qin et al. 2011). Endophytic bacteria residing in inner parts of plant tissue produce secondary metabolites with diverse pharmacological activities, similar to their host plants (Egamberdieva et al. 2017a; Gouda et al. 2016). Therefore, they are considered a potential source of biologically active compounds with high therapeutic potential. These findings show the potential of biologically active compounds such as alkaloids, coumarins, steroids, glycosides, flavonoids, tannins, and essential oils as candidates for developing antimicrobial drugs for the prevention/treatment of infectious diseases.

\section{Future prospects}

Considering the vital role of medicinal plants in the global population's well-being, more of them should be researched as protection alternatives for synthetics. Demand for medicinal and aromatic plants in Uzbekistan and other developing countries should continue for the near future. The utilization of unique indigenous knowledge of using medicinal plants to heal human ailments has a great potential to create cost-effective solutions and to screen natural products for drug discovery. Since the medicinal plant-associated microbes also produce various biologically active compounds as their host plant, a more data-rich investigation of these extraordinary microbiome properties as a potential source for new antimicrobials is essential. Moreover, it will help in elucidating pathways and mechanisms of novel biologically active compounds from medicinal plants and their mutualistic microbes, which can be formulated as antimicrobial agents. Furthermore, plant tissue culture is a promising alternative for the production of biologically active compounds of medical importance and should be explored further.

\section{Conclusion}

The herbal plants grown in Uzbekistan are very diverse, endemic, and contain various biologically active compounds. Although many plant species are reported 
as sources of medicine and play a key role in human health management, their phytochemical and biological properties are less studied. They contain various biologically active compounds, which could help discover novel drugs. Therefore, there is an urgent need to continue ethnobotanical research to find and document important medicinal plants endemic to the region and investigate their potential for antimicrobial drug discovery. The present report described the current status of the medicinal plants from Uzbekistan and provided insight into herbal plants' antimicrobial properties and the justification for continuing search for novel metabolites from them. The utilization of ethnomedicinal knowledge has excellent potential to discover possible antimicrobial compounds from the medicinal plants and their associated microbes (Fig. 1).

Acknowledgements The authors are thankful to the Head of Faculty of Ecology, Dr. Rustamjon Allaberdiev for his support and cooperation in data collection. We state that this manuscript has not been published elsewhere and also is not submitted for publication elsewhere. All authors approved manuscript and agreed on content.

Funding Open Access funding enabled and organized by Projekt DEAL.

\section{Compliance with ethical standards}

Conflict of interest The authors declare no conflict of interest.

Ethical approval This Manuscript does not contain any studies with human participants or animals performed by any of the authors.

Open Access This article is licensed under a Creative Commons Attribution 4.0 International License, which permits use, sharing, adaptation, distribution and reproduction in any medium or format, as long as you give appropriate credit to the original author(s) and the source, provide a link to the Creative Commons licence, and indicate if changes were made. The images or other third party material in this article are included in the article's Creative Commons licence, unless indicated otherwise in a credit line to the material. If material is not included in the article's Creative Commons licence and your intended use is not permitted by statutory regulation or exceeds the permitted use, you will need to obtain permission directly from the copyright holder. To view a copy of this licence, visit http://creativecommons.org/licenses/by/4.0/.

\section{References}

Aldashev AA (1979) Aconitum: pharmacology, toxicology, and uses. Ilim, Frunze (in Russian)

Azizov UM, Khadzhieva UA, Rakhimov DA, Mezhlumyan LG, Salikhov SA (2012) Chemical composition of dry extract of Arctium lappa roots. Chem Nat Compounds 47(6):1038-1039

Bahramsoltani R, Farzaei MH, Rahimi R (2014) Medicinal plants and their natural components as future drugs for the treatment of burn wounds: an integrative review. Arch Dermatol Res 306(7):601-617
Baser KHC, Demircakmak B, Nuriddinov KhR, Nigumatullaev AM, Aripov KhN (1997) Composition of the essential oil of Origanum tyttanthum Gontsch. from Uzbekistan. J Essent Oil Res 9:611-612

Baser KHC, Nuriddinov HR, Ozek T, Demirci B, Azcan N, Nigmatullaev AM (2002) Essential Oil of Arischrada korolkowii from the Chatkal Mountains of Uzbekistan. Chem Nat Compd 38:51-53. https://doi.org/10.1023/A:1015729731464

Bedir E, Khan IA, Walker LA (2002) Biologically active steroidal glycosides from Tribulus terrestris. Pharmazie 57(7):491-493

Betoni JEC, Mantovani RP, Barbosa LN, Di Stasi LC, Fernandes JA (2006) Synergism between plant extract and antimicrobial drugs used on Staphylococcus aureus diseases. Memórias Inst Oswaldo Cruz 101(4):387-390

Blagojevic P, Radulovic N, Palic R, Stojanovic G (2006) Chemical composition of the essential oils of Serbian wild-growing Artemisia absinthium and Artemisia vulgaris. J Agricult Food Chem 54(13):4780-4789

Buranova DD (2015) The value of Avicenna's heritage in the development of modern integrative medicine in Uzbekistan. Integr Med Res 4(4):220-224

Chen S, Yu H, Luo H, Wu Q, Li CF, Steinmetz A (2016) Conservation and sustainable use of medicinal plants: problems, progress, and prospects. Chin Med 11:37

Climati E, Mastrogiovanni F, Valeri M, Salvini L, Bonechi C, Mamadalieva NZ, Tiezzi A (2013) Methyl carnosate, an antibacterial diterpene isolated from Salvia officinalis leaves. Natl Product Commun 8(4):429-430

Compean KL, Ynalvez RA (2014) Antimicrobial activity of plant secondary metabolites: a review. Res J Med Plants 8(5):204-213

Curini M, Epifano F, Genovese S, Tammaro F, Menghini L (2006) Composition and antimicrobial activity of the essential oil of Artemisia dracunculus "piemontese" from italy. Chem Natural Comp 42(6):738-739

Cushnie TT, Lamb AJ (2005) Antimicrobial activity of flavonoids. Intern J Antimicrob Agents 26(5):343-356

Dall'Agnol R, Ferraz A, Bernardi AP, Albring D, Nor C, Sarmento L, Schapoval EES (2003) Antimicrobial activity of some Hypericum species. Phytomedicine 10(6-7):511-516

Duarte MCT, Figueira GM, Sartoratto A, Rehder VLG, Delarmelina C (2005) Anti-Candida activity of Brazilian medicinal plants. J Ethnopharm 97(2):305-311

Duraipandiyan V, Ignacimuthu S (2011) Antifungal activity of traditional medicinal plants from Tamil Nadu. India Asian Pacific J Tropical Biomed 1(2):S204-S215

Egamberdieva D, da Silva JAT (2015) Medicinal plants and PGPR: a new frontier for phytochemicals. In: Egamberdieva et al. (Eds.) Plant-growth-promotingrhizobacteria (PGPR) and medicinal plants, Springer, Cham, pp. 287-303

Egamberdieva D, Jabborova D (2018) Medicinal plants of Uzbekistan and their traditional uses. In: Egamberdieva and Ozturk (Eds.). Vegetation of Central Asia andEnvirons, Springer, Cham, pp. 211-237

Egamberdieva D, Mamadalieva N, Khodjimatov O, Tiezzi A (2013) Medicinal plants from Chatkal Biosphere Reserve used for folk medicine in Uzbekistan. Med Aromat Plant Sci Biotechnol 7(1):56-64

Egamberdieva D, Mamedov N, Ovidi E, Tiezzi A, Craker L (2017) Phytochemical and pharmacological properties of medicinal plants from Uzbekistan: a review. J Medicinally Active Plants 5(2):59-75

Egamberdieva D, Wirth S, Behrendt U, Ahmad P, Berg G (2017) Antimicrobial activity of medicinal plants correlates with the proportion of antagonistic endophytes. Front Microbiol 8:199

Egamberdieva D, Shurigin V, Alaylar B, Birkeland NK, Wirth S, Kimura SKB (2020) Bacterial endophytes from horseradish 
(Armoracia rusticana) with antimicrobial efficacy against pathogens. Plant Soil Envir 66:309-316

Eisenman SW, Zaurov DE, Struwe L (2013) Medicinal plants of Central Asia: Uzbekistan and Kyrgyzstan. Springer

Gaipova NN, Kariyeva ES (2018) The market of medicinal plant raw materials of Uzbekistan. Pharmaceutical J 4:Article 1

Gnat S, Zieba P, Majer-Dziedzic B, Nowakiewicz A, Trościańczyk A, Ziółkowska G, Dziedzic R (2017) Antimicrobial activity of some plant extracts against bacterial pathogens isolated from faeces of red deer (Cervus elaphus). Polish J Veterinary Sci 20(4):697-706

Gouda S, Das G, Sen SK et al (2016) Endophytes: a treasure house of bioactive compounds of medicinal importance. Front Microbiol 7:1538

Gupta N, Jain UK (2010) Prominent wound healing properties of indigenous medicines. J Natural Pharm 1(1):2-13

Iacobellis NS, Lo Cantore P, Capasso F, Senatore F (2005) Antibacterial activity of Cuminum cyminum L. and Carum carvi L. essential oils. J Agric Food Chem 53(1):57-61

Khalmatov KhKh (1964) Dikorastushchiye Lekarstvenniye Rasteniya Uzbekistana (Wild-growing medicinal plants of Uzbekistan). Meditsina, Tashkent (in Russian)

Khalmatov KhKh, Kharlamov IA, Alimbayeva PK, Karriev MO, Khaetov IH (1984) Osnovnuiye lekarstvennuiye rasteniya Srednei Azii (The main medicinal plants of Central Asia). Meditsina, Tashkent (in Russian)

Khodzhimatov M (1989) Dikorastushchiye Lekarstvennuiye Rasteniya Tadzhikistana (Wild-growing medicinal plants of Tadjikistan). Glavnaya nauchnaya redaktsiya Tadzhikskoi Sovetckoi entsiklopedii, Dushanbe (in Russian)

Kholmatov Kh, Makhsumov M (1993) Medicinal plants for treating colds. Ibn Sino, Tashkent

Kianfé BY, Kühlborn J, Tchuenguem TR, Tchegnitegn BT, Ponou BK, Groß J, Teponno RB, Dzoyem JP, Opatz T, Tapondjou LA (2020) Antimicrobial secondary metabolites from the medicinal plant Crinum glaucum A. Chev. (Amaryllidaceae). South African J Botany 133:161-166

Kogure K, Yamauchi I, Tokumura A, Kondou K, Tanaka N, Takaishi Y, Fukuzawa K (2004) Novel antioxidants isolated from plants of the genera Ferula, Inula, Prangos and Rheum collected in Uzbekistan. Phytomedicine 11(7-8):645-651

Kumarasamy Y, Cox PJ, Jaspars M, Nahar L, Sarker SD (2002) Screening seeds of scottish plants for antibacterial activity. J Ethnopharm 83(1-2):73-77

Kwon DH, Kwon HY, Kim HJ, Chang EJ, Kim MB, Yoon SK, Song EY, Yoon DY, Lee YH, Choi IS, Choi YK (2005) Inhibition of hepatitis B virus by an aqueous extract of Agrimonia eupatoria L. Phytother Res 19(4):355-358

Mamadalieva NZ (2012) Phytoecdysteroids from Silene plants: distribution, diversity and biological (antitumour, antibacterial and antioxidant) activities. Boletín Latinoamericano Caribe Plantas Med Aromáticas 11(6):474-497

Mamadalieva N, Syrov V, Egamberdieva D, Jones V (2008) Phytoecdysteroids from Silene viridiflora and their actoprotective, adaptogenic and antimicrobial activity: YSF-76. Febs J 275(1):457

Mamadalieva NZ, Herrmann F, El-Readi MZ, Tahrani A, Hamoud R, Egamberdieva DR, Wink M (2011) Flavonoids in Scutellaria immaculata and S. ramosissima (Lamiaceae) and their biological activity. J Pharmacy Pharmacology 63(10):1346-1357

Mamadalieva NZ, Egamberdieva D, Tiezzi A (2013) In vitro biological activities of the components from Silene wallichiana. Med Aromatic Plant Sci Biotechnol 7(1):1-6

Mamadalieva NZ, Youssef FS, Ashour ML, Sasmakov SA, Tiezzi A, Azimova SS (2018) Chemical composition, antimicrobial and antioxidant activities of the essential oils of three Uzbek Lamiaceae species. Nat Prod Res 33(16):2394-2397
Mamedov N, Craker LE (2001) Medicinal plants used for the treatment of bronchial asthma in Russia and Central Asia. J Herbs, Spices Med Plants 8(2-3):91-117

Mamedov N, Gardner Z, Craker LE (2004) Medicinal plants used in Russia and Central Asia for the treatment of selected skin conditions. J Herbs Spices Med Plants 11(1-2):191-222

McChesney JD, Venkataraman SK, Henri JT (2007) Plant natural products: back to the future or into extinction? Phytochemistry 68(14):2015-2022

Minayeva VG (1991) Lekarstvennuiye Rasteniya Sibiri, 5 izd (Medicinal plants of Siberia), 5th edn. Nauka, Novosibirsk (in Russian)

Mishra MP, Rath S, Swain SS, Ghosh G, Das D, Padhy RN (2017) In vitro antibacterial activity of crude extracts of 9 selected medicinal plants against UTI causing MDR bacteria. J King Saud Univ 29(1):84-95

Murillo-Alvarez JI, Encarnación DR, Franzblau SG (2001) Antimicrobial and cytotoxic activity of some medicinal plants from Baja California Sur (Mexico). Pharm Biology 39(6):445-449

Musa Z, Ma J, Egamberdieva D, Mohamad O, Liu YH, Li WJ, Li L (2020) Diversity and antimicrobial potential of cultivable endophytic actinobacteria associated with medicinal plant Thymus roseus. Front Microbiol. https://doi.org/10.3389/fmicb .2020 .00191

Neipihoi NB, Saikia S, Saikia S, Tamuli KJ, Sahoo RK, Dutta D, Bordoloi M (2020) Anticancer and antimicrobial compounds from Croton caudatus Gieseler and Eurya acuminata DC: two edible plants used in the traditional medicine of the Kuki tribes. Nat Prod Res. https://doi.org/10.1080/14786419.2020.1815737

Nikolic M, Jovanovic KK, Markovic T, Markovic D, Gligorijevic N, Radulovic S, Sokovic M (2014) Chemical composition, antimicrobial, and cytotoxic properties of five Lamiaceae essential oils. Industrial Crops Products 61:225-232

Norouzi-Arasi H, Yavari I, Chalabian F, Kiarostami V, Ghaffarzadeh F, Nasirian A (2006) Chemical constituents and antimicrobial activities of the essential oil of Acroptilon repens (L.) DC. Flavour Fragrance J 21(2):247-249

Nuraliyev Y, Zubaidova T (1994) Hypocholesterinemic and hypolipidemic effects of ether oil of Origanum tyttanthum Gontsch. Khimiko-Farm Zh 28:63-64

Park CJ, Park CB, Hong SS, Lee HS, Lee SY, Kim SC (2000) Characterization and cDNA cloning of two glycine-and histidinerich antimicrobial peptides from the roots of shepherd's purse Capsella bursa-pastoris. Plant Mol Biol 44(2):187-197

Pirbalouti AG, Jahanbazi P, Enteshari S, Malekpoor F, Hamedi B (2010) Antimicrobial activity of some Iranian medicinal plants. Arch Biol Sci 62(3):633-641

Qader MK, Khalid NS, Abdullah AM (2013) Antibacterial activity of some plant extracts against clinical pathogens. Int J Microbiol Immunol Res 1(5):53-56

Qin Sh, Xing K, Jiang JH et al (2011) Biodiversity, bioactive natural products and biotechnological potential of plant-associated endophytic actinobacteria. Appl Microbiol Biotechnol 89(3):457-473

Rustamova N, Wubulikasimu A, Gao Y, Egamberdieva D, Yili A, Aisa HA (2020) Endophytic bacteria associated with medicinal plant Baccharoides anthelmintica - diversity and characterization. Curr Microbiol. https://doi.org/10.1007/s00284-020-01924-5

Şahin F, Güllüce M, Daferera D, Sökmen A, Sökmen M, Polissiou M, Özer H (2004) Biological activities of the essential oils and methanol extract of Origanum vulgare ssp. vulgare in the Eastern Anatolia region of Turkey. Food Control 15(7):549-557

Sapkota R, Dasgupta R, Rawat DS (2012) Antibacterial effects of plants extracts on human microbial pathogens \& microbial limit tests. Int J Res Pharm Chem 2(4):926-936 
Sardari S, Amin G, Micetich RG, Daneshtalab M (1998) Phytopharmaceuticals. Part 1. Antifungal activity of selected Iranian and Canadian plants. Pharmaceutical Biol 36(3):180-188

Saslis-Lagoudakis CH, Hawkins JA, Greenhill SJ, Pendry CA, Watson MF, Tuladhar-Douglas W et al (2014) The evolution of traditional knowledge: environment shapes medicinal plant use in Nepal. Proc Royal Soc B: Biol Sci 281(1780):20132768

Sezik E, Yesilada E, Shadidoyatov H, Kulivey Z, Nigmatullaev AM, Aripo HN, Honda G (2004) Folk medicine in Uzbekistan: I. Toshkent, Djizzax, and Samarqand provinces. J Ethnopharm 92(2-3): 197-207

Shrivastava S, Egamberdieva D, Varma A (2015) PGPRs and medicinal plants- the state of arts. In: Egamberdieva D, Shrivastava S, Varma A (eds) Plant Growth-Promoting Rhizobacteria (PGPR) and Medicinal Plants. Springer, Verlag, pp 1-16

Shurigin V, Davranov K, Wirth S, Egamberdieva D, BellingrathKimura SD (2018) Medicinal plants with phytotoxic activity harbour endophytic bacteria with plant growth inhibitory properties. Environ Sustain 1(2):209-215

Sonboli A, Mirjalili MH, Hadian J, Ebrahimi SN, Yousefzadi M (2006) Antibacterial activity and composition of the essential oil of Ziziphora clinopodioides subsp. bungeana (Juz.) Rech. f. from Iran. Zeitschrift Naturforschung C 61(9-10):677-680

Tada Y, Shikishima Y, Takaishi Y, Shibata H, Higuti T, Honda G, Ohmoto Y (2002) Coumarins and $\gamma$-pyrone derivatives from Prangos pabularia: antibacterial activity and inhibition of cytokine release. Phytochemistry 59(6):649-654

Tamemoto K, Takaishi Y, Chen B, Kawazoe K, Shibata H, Higuti T, Ashurmetov O (2001) Sesquiterpenoids from the fruits of Ferula kuhistanica and antibacterial activity of the constituents of $F$. kuhistanica. Phytochemistry 58(5):763-767

Ushimaru PI, Silva MTND, Di Stasi LC, Barbosa L, Fernandes JA (2007) Antibacterial activity of medicinal plant extracts. Braz J Microbiol 38(4):717-719

Vanitha V, Vijayakumar S, Nilavukkarasi M, Punitha VN, Vidhya E, Praseetha PK (2020) Heneicosane-a novel microbicidal bioactive alkane identified from Plumbago zeylanica L. Industrial Crops Products 154:112748

Verma V, Singh R, Tiwari RK, Srivastava N, Verma A (2012) Antibacterial activity of extracts of Citrus, Allium and Punica against food borne spoilage. Asian J Plant Sci Res 2(4):503-509

Yili A, Aisa HA, Maksimov VV, Veshkurova ON, Salikhov SI (2009) Chemical composition and antimicrobial activity of essential oil from seeds of Anethum graveolens growing in Uzbekistan. Chem Natl Compounds 45(2):280-281

Yuldasheva NK, Ul'chenko NT, Mamadalieva N, Glushenkova AI, Ovidi E, Triggiani D, Tiezzi A (2014) Lipids from the aerial part of Scutellaria ramosissima. Chem Nat Comp 50(1):68-71

Zaidi MA, Crow JSA (2005) Biologically active traditional medicinal herbs from Balochistan. Pakistan J Ethnopharm 96(1-2):331-334

Publisher's Note Springer Nature remains neutral with regard to jurisdictional claims in published maps and institutional affiliations. 